DOI: $10.6060 / \mathrm{mhc} 130538 \mathrm{k}$

\title{
Fluorescence Detected Induced Circular Dichroism Observed for Optically Active Binaphthyl-Linked Metal-Free and Zinc Phthalocyanines
}

\author{
Nagao Kobayashi \\ Dedicated to Professor Evgenij A. Lukyanets on the ocassion of his $75^{\text {th }}$ Birthday \\ Department of Chemistry, Graduate School of Science, Tohoku University, Sendai 980-8578, Japan \\ E-mail:nagaok@m.tohoku.ac.jp
}

\begin{abstract}
Zinc and metal-free phthalocyanines (Pcs) with four optically active binaphthyl units on the periphery showed both fluorescence-detected circular dichroism (FDCD, in ca. 200-270 nm) and fluorescence detected induced circular dichroism (FDICD, ca. 270-700 nm). FDICD signal was positive for (R)-binaphthayl linked species while negative for (S)-binaphthayl linked Pcs.
\end{abstract}

Keywords: Optically active phthalocyanine, fluorescence detected induced circular dichroism, binaphthyl.

\section{Наблюдение флюоресцентно-детектируемого иняуцированного кругового Аихроизма Аля оптически активного фталоцианина с бинафтильными фрагментами и его цинкового комплекса}

\section{Н. Кобаяши}

Посвящается профессору Евгению Антоновичу Лукьянцу по случаю его 75-летнего юбилея

Department of Chemistry, Graduate School of Science, Tohoku University, Сендай 980-8578, Япония

E-mail:nagaok@m.tohoku.ac.jp

\begin{abstract}
Безметальный фталоцианин (Рcs) с четырьмя периферическими оптически активными бинафтильныли фрагментами и его ичнковый комплекс проявляют как флуоресцентно-детектируемый круговой дихроизм (ФДКД, при 200-270 нм) так и флуоресиентно-детектируемый индуцчированный круговой дихроизм (ФДИКД, при 270-700 нм). Для фталоцианинов с (R)-бинафтильными фрагментами сигнал ФДИКД положителен, а с (S)-бинафтильныли - отрицателен.
\end{abstract}

Ключевые слова: Оптически активные фталоцианины, флуоресцентно-детектируемый индуцированный круговой дихроизм, бинафтильные заместители.

\section{Introduction}

While CD measures the difference in absorption for leftand right-circularly polarized light, ${ }^{[1]}$ fluorescence-detected circular dichroism (FDCD) detects the difference in fluorescence intensity for left- and right-circularly polarized excita- tions. Namely, in FDCD, the excitation alternates between left- and right-circularly polarized light, and the difference in the emission intensity is measured. Under standard conditions, when the emission of a sample is directly proportional to absorbance, the same dichroic information can be obtained from both processes. Since fluorescence directly measures 
the amount of light emitted against zero background while absorbance is determined from an intensity difference of transmitted light, the fluorescence signal typically can be observed at much lower concentrations than absorbance, so that it is known that FDCD measurement results in 50-100-fild sensitivity enhancement over conventional $\mathrm{CD}^{[2,3]}$ In particular, in the case of tetraphenylporphyrin fluorophore having $\varepsilon \sim c a$. $440000 \mathrm{~mol}^{-1} \mathrm{dm}^{3} \mathrm{~cm}^{-1}$, even $10^{-10} \mathrm{M}$ concentration could be used to detect reliable FDCD signals. ${ }^{[4]}$

In this communication, we report the first example of fluorescence-detected induced CD (FDICD). In order to observe FDICD, the fluorophore should have a large extinction coefficient, $\varepsilon$, and a known direction of the electric transition moment, $\mu$, and hopefully a high fluorescence quantum yield and chemical stability. The compounds in this study are the metalfree and zinc complexes of binaphthyl-linked phthalocyanine $\left(\mathrm{Np}_{4} \mathrm{H}_{2}\right.$ and $\mathrm{Np}_{4} \mathrm{Zn}$, respectively) (Figure 1) we reported previously. ${ }^{[5]}$ In these compounds, the mutual position of binaphthyl units and the Pc core is well established, and they show strong induced $\mathrm{CD}$ due to the closely linked four optically active binaphthyl units. The sign and intensity of the CD bands have also been minutely and precisely elucidated.

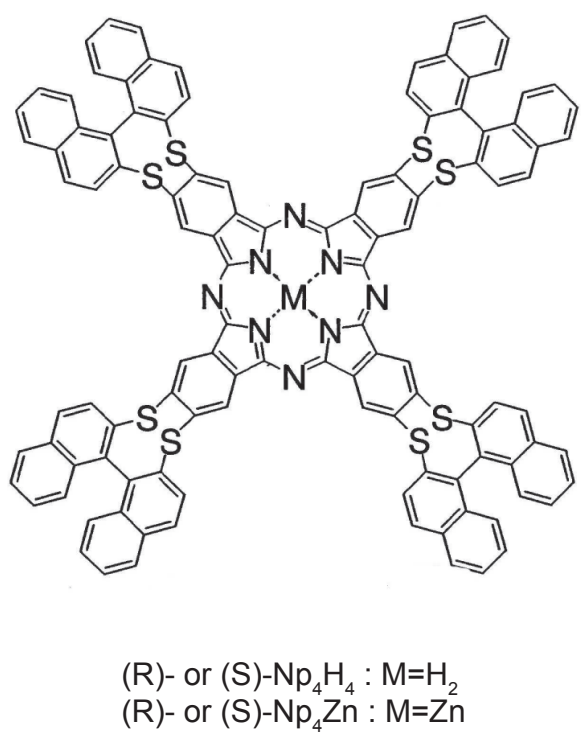

Figure 1. Structures of $\mathrm{Np}_{4} \mathrm{H}_{2}$ and $\mathrm{Np}_{4} \mathrm{Zn}$. $(R)$ and $(S)$ represent the configuration of the binaphthyl moiety. $(R)$ - and $(S)$-Binaphthyl are left- and right-handed conformer, respectively (attention must be paid to the fact that for most of the organic molecules, $(R)$ - and $(S)$ generally means right and left-handed conformer, respectively).

\section{Experimental}

Compounds: (R)- and (S)-Np $\mathrm{H}_{4}$ and $\mathrm{Np}_{4} \mathrm{Zn}$. These compounds were those we used in our previous study. ${ }^{[5]}$

Equipments: In order to avoid the so-called re-absorption effect, the solutions for FDICD measurement had maximal absorbance below 0.2. The low concentration conjectured from this low absorbance also helped in reducing the intermolecular fluorescence quenching being effective at higher concentrations. A

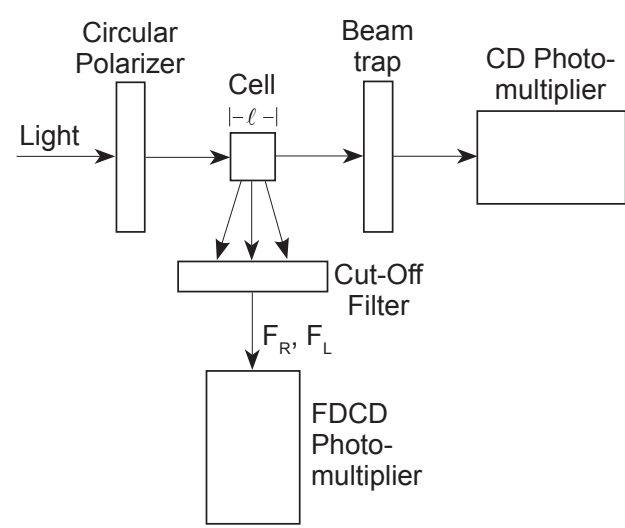

Figure 2. A diagram showing how fluorescence detection of FDCD and FDICD compare with the normal method. The FDCD detector in principle can be placed at any angle relative to the incident light, but in our case it was 90 degree.

JASCO-720 spectropolarimeter was fitted with a JASCO prototype FDCD attachment (containing a Hamamatsuphotonics R736 photomultiplier tube), with the fluorescence detector placed at $90^{\circ}$ to the exciton beam (Figure 2) ${ }^{[6]}$ The transmitted light was trapped by a Rayleigh horn beam trap placed between the sample and CD detector. The bandwidth was $2 \mathrm{~nm}$, and the voltage applied to the detector was always kept between 400 and $800 \mathrm{~V}$, corresponding to a maximal DC output signal voltage from the detector of $1.0 \mathrm{~V}$. For FDICD measurements, the emitted light that is detected can be controlled by varying the cut off of a long-pass filter placed between the sample and the fluorescence detector.

The appropriate filters were chosen in order to avoid scattered light from the excitation wavelength which could contaminate the observed emission. In cases where scatter of the excitation wavelengths overlapped with the emission range, it was of primary concern to adjust the filter to a longer wavelength to eliminate the scattered excitation light.

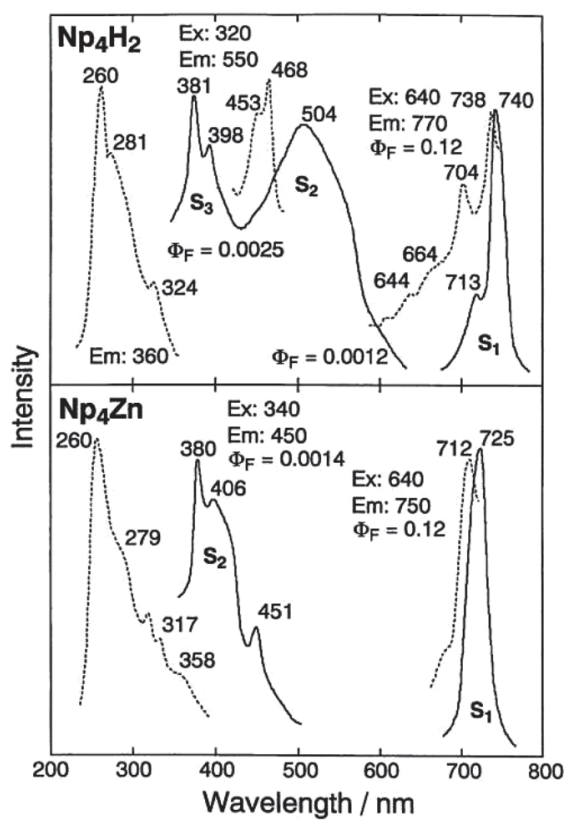

Figure 3. Fluorescence and excitation spectra of $\mathrm{Np}_{4} \mathrm{H}_{2}$ and $\mathrm{Np}_{4} \mathrm{Zn}$ in $\mathrm{CHCl}_{3}$. The excitation and emission wavelengths used to record the excitation spectra are provided along with the quantum yields. 
Fluorescence emission and excitation spectra were collected on HITACHI F-4500 spectrofluorometer, and the quantum yields $\left(\Phi_{\mathrm{F}}\right)$ were determined by a relative method using substituentfree $\mathrm{H}_{2} \mathrm{Pc}$ and $\mathrm{ZnPc}$ in 1-chloronaphthalene $\left(\Phi_{\mathrm{F}}=0.60\right.$ and 0.30 , respectively $)^{[7]}$ and quinine bisulfate in $1 \mathrm{~N} \mathrm{H}_{2} \mathrm{SO}_{4}\left(\Phi_{\mathrm{F}}=0.55\right)$ as standards ${ }^{[8]}$ by employing the refractive index squared correction. ${ }^{[9]}$

\section{Results and Discussion}

Figure 3 shows the fluorescence emission and excitation spectra of $\mathrm{Np}_{4} \mathrm{H}_{2}$ and $\mathrm{Np}_{4} \mathrm{Zn}$. Not only S1 but also S2 emission are reported from time to time for porphyrinoids, ${ }^{[10]}$ although the latter may need to be re-evaluated on the basis of a recent study, which called into question whether S2 emission is actually the result of an impurity generated by photodegradation. ${ }^{[11]}$ As for the other Pc ligands that have been reported to date, ${ }^{[12-14]}$ the Stokes Shift of the S1 emission is very small, while that of the apparent S2 emission is large. Compared with Pcs with normal substituent groups, the S1 emission appears at somehow longer wavelength and the quantum yields $\left(\Phi_{\mathrm{F}}=0.12\right)$ are slightly smaller than those reported previously, since non radiative decay becomes easier with increasing wavelength. The $\Phi_{\mathrm{F}}$ values of the apparent S2 emission were the largest ever to be reported for Pcs. ${ }^{[10]}$

Figure 4 shows the FDCD and FDICD spectra in this study. The $c a$. 220-270 nm region is the FDCD of binaphthyl

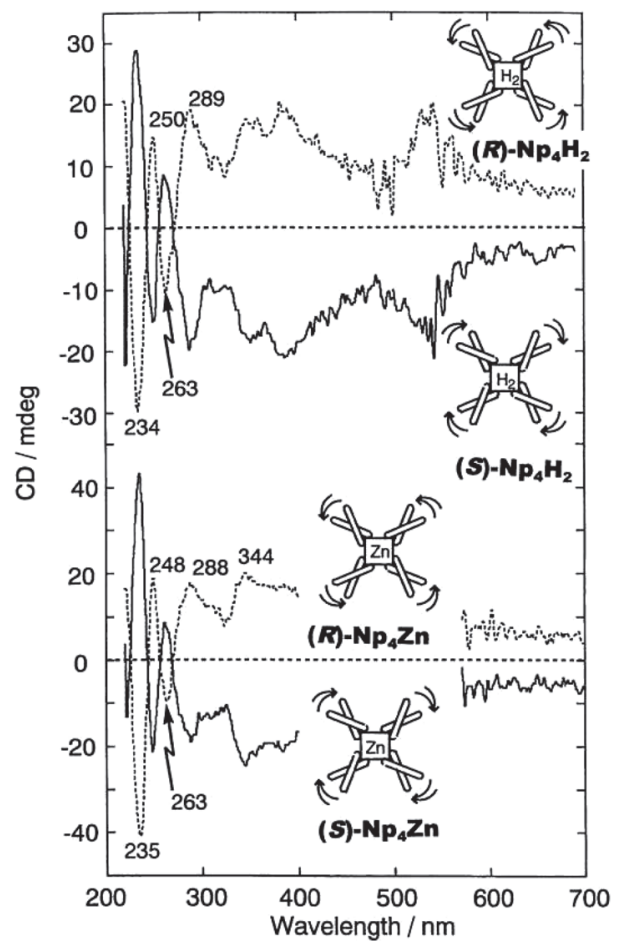

Figure 4. FDCD (less than ca. $270 \mathrm{~nm}$ ) and FDICD (ca. 270-700 nm) spectra of $\mathrm{Np}_{4} \mathrm{H}_{2}$ and $\mathrm{Np}_{4} \mathrm{Zn}$ in THF. The FDICD spectra of $\mathrm{Np}_{4} \mathrm{Zn}$ in 400-500 nm are not shown because of excessive noise. Concentrations of samples used for the measurements of FDICD were as follows: $5.30 \cdot 10^{-6} \mathrm{~mol} / 1$ for $\mathrm{Np}_{4} \mathrm{H}_{2}$ and $1.34 \cdot 10^{-6} \mathrm{~mol} / \mathrm{l}$ for $\mathrm{Np}_{4} \mathrm{Zn}$. units, and the shape and sign are almost identical as those of conventional CD. ${ }^{[5]}$ This suggests that the split energy level arising from exciton coupling (of binaphthyl moiety) is preserved in the emission stage as well. The region longer than $c a .270 \mathrm{~nm}$ is the FDICD spectra, since this region of the $\mathrm{CD}$ spectra are induced $\mathrm{CD}$ due to binaphthyl units. ${ }^{[5]}$ The sign of the FDICD spectra of the S1 and S2 emission was positive for the $(R)$ species (left-handed conformer) and negative for the $(S)$ species, suggesting that the $(R)$ species absorbs left-circularly polarized light more than the right, and vice versa for the $(S)$ species (right-handed conformer).

\section{Conclusions}

Unfortunately, we can not discuss on the FDICD spectra more than this, since no theory has been reported on the FDICD to date. The most important experimental fact in this communication is that the sign of the FDICD spectra of the emission was positive for the $(R)$ species (left-handed conformer) and negative for the $(S)$ species, suggesting that the $(R)$ species absorbs left-circularly polarized light more than the right, and vice versa for the $(S)$ species (right-handed conformer), although the observed splitting in the emission may have the other reason which may be not directly connected with the excitonic interactions.

\section{References}

1. Kobayashi N., Muranaka A., Mack A. Circular Dichroism and Magnetic Circular Dichroism Specroscopy for Organic Chemists. London: Royal Society of Chemistry, 2011.

2. Dong J.G., Wada A., Takakuwa T., Nakanishi K., Berova N. J. Am. Chem. Soc. 1997, 119, 12024-12025.

3. Nehira T., Parish C.A., Jockusch S., Turro N.J., Nakanishi K., Berova N. J. Am. Chem. Soc. 1999, 121, 8681-8691.

4. Tanaka K., Pescitelli G., Nakanishi K., Berova N. Monat. Chem. 2005, 136, 367-395.

5. Kobayashi N., Higashi R., Titeca B.C., Lamote F., Ceulemans A. J. Am. Chem. Soc. 1999, 121, 12081-12091.

6. Tinoco Jr. I., Turner D.H. J. Am. Chem. Soc. 1976, 98, 6453.

7. Seybold P.G., Gouterman M. J. Mol. Spectrosc. 1969, 31, 1-13.

8. a) Melhuish W. J. Phys. Chem. 1960, 64, 762-764; b) Demas J.N., Crosby G.A. J. Phys. Chem. 1971, 75, 991-1024.

9. Morris J.V., Mahaney M.A., Huber J.R. J. Phys. Chem. 1976, 80, 969-974.

10. Ishii K., Kobayashi N. In: The Porphyrin Handbook [Kadish K.M., Smith K., Guilard R., Eds.]. Academic Press, NewYork, Ch. 102, 2003.

11. Mack J., Kobayashi N., Stillman M.J. J. Inorg. Biochem. 2010, 102, 472-479.

12. Kobayashi N., Lam H., Nevin W.A., Janda P., Leznoff C.C., Koyama T., Monden A., Shirai H. J. Am. Chem. Soc. 1994, 116, 879-890.

13. Kaneko Y., Nishimura Y., Takane N., Arai T., Sakuragi H., Kobayashi N., Matsunaga D., Pac C., Tokumaru K. J. Photochem. Photobiol. A: Chem. 1997, 106, 177-183.

14. Kobayashi N., Togashi M., Osa T., Ishii K., Yamauchi S., Hino H. J. Am. Chem. Soc. 1996, 118, 1073-1085. 